\title{
Mutual relation and boundaries of Ecology Law and the other law branches
}

\author{
Vladan Joldzik \\ vladanj@eunet.rs \\ Professor at the High School of Law \\ University of Novi Sad, \\ and at Singidunum University \\ University of Belgrado
}

Recebido em 12/02/2011

Aprovado em 02/09/2011

\begin{abstract}
Resumo
Relações Mútuas e Limites do Direito Ecológico e outros ramos do direito trata de algumas questões sobre relações mútuas e busca estabelecer limites precisos entre o direito ambiental e outros ramos do direito: direito constitucional, direito internacional, direito administrativo, direito civil e direito penal.
\end{abstract}

\section{Palavras-chave}

Relações lógicas. Limites. Direito Ecológico. Direito constitucional. Direito internacional. Direito administrativo. Direito civil. Direito penal. 


\title{
Relação mútua e limites do Direito Ecológico e outros ramos do Direito
}

\author{
Vladan Joldzik
}

Abstract

Mutual Relation and Boundaries of Ecology Law and the Other Law Branches treats some questions about mutual relations and try to state precisely boundaries between environmental and the other law branches: Constitutional Law, International Public Law, Administrative Law, Civil Law and Penal Law.

Key words

Logical relations and boundaries. Environmental law. Constitutional Law. International Public Law. Administrative Law. Civil Law. Penal Law. 


\section{Sumário}

1 Principle Remarks

2 Relation between Ecology and Constitutional Law

3 Relation between Ecology Law and the International Public Law

4 Relation between Ecology Law and Administrative Law

5 Relation between Ecology Law and Civil Law

6 Relation between Ecology Law and Penal Law

7 Conclusions

Bibliography 


\section{Principle Remarks}

By coming into study of the Ecology Law, which is, by no doubt, very complex, evidently multi-disciplinary law branch in development ${ }^{1}$, we think that it is necessary, on the very start of our scientific efforts, to answer at the question of mutual relations of the Ecology Law and the other law branches, form the reason of understanding the Environmental Law logic, fundaments, processes and possible results.

In a picture of law system, Brazilian, Serbian, French or any other, its elements and their mutual relations, determining fact is subject of arrangement of concrete law branch espied through positive legal rules. In accordance with long time present opinion of some number of lawyers, entire positive law is able to divide into four groups:

First group would be made of regulations, which establishes bases of society state, as well as human rights: Constitutional Law regulations ${ }^{2}$,

Second one, elements of legislations, which regulate relation toward material values on the socio-economic settlement of state $^{3}$,

Third, regulations that establish human rights in reproduction ${ }^{4}$, and:

- At the fourth group of regulations are those norms, which deal with questions of rights, duties and procedures from the aspect of administrative or similar law branch ${ }^{5}$.

1 Topics on Environmental Law development see at: JOLDZIC, Vladan: Ecology Law - General part - Or on the Elements Necessary for the establishing and existing of the Independent Law Discipline (Personal Observations). Revista Mestrado em Direito. Direitos Humanos Fundamentais, Vol. 9, No 1, Osasco: UNIFIEO - Centro Universitario FIEO, 2009, p. 127-169.

2 On the Constitutional Law fundaments, especially for Environmental law, see more at: JOLDZIC, Vladan: Constitutional - Legal Fundaments of the Environmental Protection in the Federal Republic of Yugoslavia; Belgrade (Serbia): Environment: Federal Ministry for Development, Science and Environment, No 1, 1995, p. 1-35.

3 Or, to say at the oher way: To formulate material-legal fundaments for environmental law norms formulating, including so colled environemtal incriminations. For formal material-legal fundaments see: JOLDZIC, Vladan: Environmental Law - General and Separate Part, Belgrade (Serbia): Institute for Criminological and Sociological Researches, 2009, pages: 69, 110 and 512.

4 Reflections on human rights in reproduction see, for example, in: BUSINESS \& HUMAN RIGHTS RESOURCE CENTRE. On the Horizon - A practical bulletin on what is ahead in the field of business $\boldsymbol{\&}$ human rights, Issue 8, London (United Kingdom): Business \& Human Rights Resource Centre, Monday 8 Dec 2008, p 1-7, at: http://www.crsdd.uqam. ca/Pages/docs/pdfMedias/On\%20the \%20Horizon\%20-\%20Issue $\% 208 \% 20-\% 20 \mathrm{Dec} \% 20$ 2008\%5B1\%5D.pdf, http://www.crsdd.uqam.ca/doc_and RENDTORFF, Jacob Dahl: Responsibility, Ethics and Legitimacy of Corporations, Copenhagen (Denmark), Editor (Publisher): Copenhagen Business School Press, Year 2009, p. 416.

5 See more at: Discusions (Rasprave), Vol. XII, Ljubljana (Slovenia): SAZU, 1981, p. 103, and DELLA CANANEA, Giacinto: Administrative Procedures and Rights in Italy: A Comparative 
Inside every mentioned group there are rules that directly, or indirectly, contributes to arrangement of the total law-ecological relation. From this reason our interest is to perceive, as accurately as possible, relation between Ecology Law and mentioned groups.

In answering the question of mutual relation and bounding of ecological and the other law branches, it is advisable, before all, to start from verification abovementioned multidisciplinary logic of Ecology Law. Professor Popovic has spoken about it in $1975^{\text {th }}$, in his book assigned for air and water protection, and again in $1980^{6}$. Today this fact is widely and long time accepted at the world's law science ${ }^{7}$.

Second step in our contemplation about ecological and the other law branches relations and logical borders inevitably applies on our method, or methods, of mutual mark of boundaries: Where stops one, and begins another law branch, particularly having in mind attitude of numerous jurists on explicit addiction of ecologically, remarkable elements from other law branches, starting by using its terminology, up to certain principles? Opposite to them, we are supporters of the attitude about autonomy of Ecology Law -- its autonomous place in law science system and positive legislatures, beginning from the fact that it has:

a. Its autonomous applying range - specific general object ${ }^{8}$, independent from the other law branches;

b. Dictionary, made during last decades, but also an number of

c. Autonomous principles.

In law theory it is usual to use two criteria to mark of boundaries between certain law branches:

1. Either, the criterion for to mark of boundaries is object treated by law rules of certain law branch, or

2. The criterion is manner - method of regulation?.

Approach, Italian Journal of Public Law, Volume 2n 1, Milano (Italy): Bocconi University, 2010, p. 207-215.

6 See: POPOVIC, Slavoljub: Water and Air Protection of the Soiling (Zaštita vazduha i voda od zagadivanja), Collection of the Law Faculty, Novi Sad (Serbia): Law Faculty of Novi Sad, 1980, p. 13-14.

7 See closer at book: TAUTENBERG, Jonson: The International Law - Some Basic Viewpoints, in: DUPUY, Rene-Jean (Editor): The Future of the International Law of the Environment, Hague (Netherland): Kluwer Law International, 1985, p. 233-237.

8 Closer reflections on specific general object defining see at: JOLDZIC, Vladan: Ecology law - general part - Or on the Elements necessary for the establishing and existing of the Independent Law Discipline (personal Observations), under number 2: - Defining of the Elements Necessary for the Existence of the Ecology Law, in: Revista Mestrado em Direito, Osasco (Brasil): UNIFIEO - Centro Universitario FIEO, ano 9, n. 1, 2009, pp. 134-136.

9 POPOVIC, Slavoljub: Administrative Law - General Part, Belgrade (Yugoslavia): Savremena administracija, 1989, p. 15. 
Speaking about the Ecology Law, we have to see how, as every law branch, it, in essence, regulates law relation - relation of a special kind. Exactly as Civil Law regulates Civil Law relation, Material Criminal Law - material-criminal law relation, Criminal Procedure Law regulates relation in criminal procedure, etc. Tautenberg Jonson comprehended it in 1984 . He spoke about necessity of realizing the fact that in last years was clearly differentiate ecology law relation as the specific kind of law relation ${ }^{10}$. It is, exactly, the subject matter of the Ecology Law branch -- key diferentia specifica, which establishes difference between Ecology Law and the other law branches.

Starting from methods of regulations, it is useful to realize that certain law branches, in regulation of mutually equal relations of the law subjects, use the coordination principle as a basic one (e.g., Civil Law), while the other branches as their fundamental regulation method utilize the subordination principle (e.g., Administrative Law). Ecology Law, exactly because of its multidisciplinarity, is based, parallel, on both methods, present in most law branches. Thus, building the elements of international law regulation assigned to ecosystem, it is relating on coordination ${ }^{11}$, while establishing law relations in states, Ecology Law (to be precise: Legislator) is going, logically, toward using of the subordination method, as a fundamental.

In scientific efforts at the field of Environmental Law, starting from previously explained elements, we have to recognize facts of mutual relations, from this reason, boundaries also, between a solid number of independent law and legal disciplines, their connections and elements of distinctions with the Environmental Law. It is logical to analyze, at the first place, relations between fundamental laws (constitutions) and the Environmental Law.

\section{Relation between Ecology and Constitutional Law}

Speaking about relation between Constitutional Law and Ecology law, it is useful to have on mind preference of Constitutional Law over the other law branches, concerning that Constitutional Law contains norms and principles, which are obliged for all law and legislature branches. In the law of contemporary countries, European before all, parallel with maturing and complexity of ecological problems, often is present phenomenon and obligation of developing constitutional rules, directly aimed on inauguration of adequate legislative regulation of ecological

10 Previously mentioned text of TAUTENBERG, J.

11 In accordance with the Vienna Convention on the Contractual Law, Done at Vienna on 23 May 1969. Entered into force on 27 January 1980. United Nations, Treaty Series, vol. 1155, p. 331. 
relations ${ }^{12}$. This had been obvious in contemporary law of the Federal Republic of Yugoslavia ${ }^{13}$, and is obvious, for example, in the actual law of the Federal Republic of Germany, Swiss Confederation, Republic of Serbia and many other states. Concerning the importance of constitutional determinations for Ecology Law developing, we think that they should be analyzed in a certain degree.

If we analyze, for example, Constitution of the Republic Serbia, we can se many elements present not only in this fundamental law of state, but in many modern constitutions, which fact is, for our analyze, of great importance. Framer of Constitution of the Republic Serbia has non ambiguously emphasized that Republic is state, based on equality of citizens ${ }^{14}$, with full respect of human freedoms and rights ${ }^{15}$, clearly ordering that freedoms, human and citizen rights ${ }^{16}$ are realizing, and duties fulfill ${ }^{17}$, upon Constitution ${ }^{18}$, simultaneously proclaiming man right on bealthy life in healtby environment ${ }^{19}$ and duty of state to take care about healthy life in healthy environment ${ }^{20}$.

12 Examples for this are: Fundamental Law of the Federal Republic of Germany, first issue of the FEDERAL LAW GAZETTE, dated 23 May 1949, as amended up to and including 20 December 1990, for theme important is version dated at the March 18, 1971, that establishes competence of the Federation at the field of fauna and flora protection, Constitution of the Greek Republic (Adopted: 11 June 1975, revised at April 6 ${ }^{\text {Th }}$ 2001, Official translation of the Parliament, Athena, Publisher: Eptalofos, Year 2004), Article 24, which establish "state obligation for the protection of the life and cultural environment," Constitution fédérale de la Confédération suisse du 18 avril 1999 (Etat le 19 février 2002), With packet of the environmental norms (articles 73. - 80.), from: www.admin.ch/ch/f/rs/101/index.html. And many others.

13 See mentioned book: JOLDZIC, Vladan: Constitutional - Legal Fundaments of the Environmental Protection in the Federal Republic of Yugoslavia.

14 Compare, for example: Constitution of the Republic of Serbia, OFFICIAL JOURNAL OF THE REPUBLIC OF SERBIA, No 83, Year 2006, Article 11, Federal Constitution of the Swiss Confederation, of April 18, 1999, version of September 18, 2001 (from: www.admin.ch/org/polit/00083/index.html?lang=en), Article 8, La Constitution du 4 octobre 1958; Révisions constitutionnelles de mars 2005 [French Constitution], Article 1, from: http://www. assemblee-nationale.fr/english/8ab.asp.

15 For example, compare with: The Constitution of Greece, Adopted on: 11 June 1975, As revised by the parliamentary resolution of April 6th 2001 of the VII Revisionary Parliament (Official translation), last updated 8 May 2007, Article 25 - Protection of Fundamental Rights, La Constitution du 4 octobre 1958; Révisions constitutinnelles de mars 2005 [French Constitution], Article 53-1. Also its' Charter for the Environment, Article 1.

16 See, for example: Constitution of the Swiss Confederation, Article 2, and The Constitution of Belgium, Coordinated text of 14 February 1994, a translation made by the Belgian Senate, version 21.1.1997, Article 23, Supra note 3(4).

17 For example, precisely defined in the Charter for the Environment, of the French Constitution.

18 See: Constitution of the Republic of Serbia, Article 1.

19 Constitution of the Republic of Serbia, Article 31, supra note 1.

20 See: Brazil Constitution, Adopted on: 5 Oct 1988, from: http://www.georgetown.edu/pdba/ Constitutions/Brazil/brtitle9.html, Article 224, supra note 1, as well as The Constitution of the Republic of Serbia, Article 31, supra note 2. 
As we saw, in modern states, constitutions ordered that state (this means: Serbian State also) brings and performs laws in area of freedoms, rights and duties of man and citizen, at first place, by establishing:

a. Human rights ${ }^{21}$, and especially

b. Responsibilities and sanctions for violation of freedoms, rights and duties of man and citizen ${ }^{22}$, and

c. Bases of environmental protection as well ${ }^{23}$.

Speaking about bases for the life of environmental protection, legislator orders quite precisely that, if we (for example observe Republic of Serbia) have right and duty to make and put in power laws applied for environmental protection, we have also right to ratify international conventions of the environmental importance too ${ }^{24}$. Man, with just ratified contracts that concern the International Environmental Law, completes duties and defines borders of positive ecological legislature. This means: of the Republic Serbia also ${ }^{25}$.

\section{Relation between Ecology Law and the International Public Law}

International Public Law at the same time represents branch of law science and group of norms who's main -- general study topic, and the object of regulation, is, before all, mutual relation between $\operatorname{states}^{26}$, as subjects of law $^{27}$. It has several branches and their sections. Most important for us among them are International Law branches that treat:

21 See: Constitution of the Republic of Serbia, Article 1.

22 For example, by Article 12, supra note 3 and 4.

23 See, for example: Constitution of the Republic of Serbia, Article 72, supra note 5, or Constitution of the Italian Republic (Costituzione della Repubblica italiana, GAZZETTA UFFICIALE, No. 298, on 27 December 1947), Article 117 (s).

24 See: Article 73, supra note 2 and 7, of the Constitution of the Republic Serbia.

25 About this moment see: JOLDZIC, V. \& MILICEVIC, G.: Constitutional - Legal Fundaments of the Environmental Protection in the Federal Republic of Yugoslavia, Edition: Environment, No. 1, Belgrade (Federal Republic of Yugoslavia): Federal Ministry for Development, Science and the Environment, 1995, p 2-5.

26 Or to say, briefly, fundamental postulate of Anzilotti's work: International law regulates reciprocity relations of the states. See more at: ANZILOTTI, Dionisio: Cours de Droit International, Vol. 1, Paris (France): Librairie du Recueil Sirey, 1929, pp. 466-534.

27 See closely at the: Encyclopedia of the Law (Enciklopedija prava), Belgrade, (Socialistic Federal Republic of Yugoslavia): Savremena dministracija, 1989, p. 794, as well at the: AVRAMOV, Sima. \& KRECA, Milenko: International Public Law (Međunarodno javno pravo), Belgrade, (Socialistic Federal Republic of Yugoslavia): Savremena dministracija, 1993, pp. 1-8, and McKEEVER, Kent: Researching Public International Law, Columbia University Law School, Library: Pegasus Arthur W. Diamond Law Library Research Guides, Last Updated January 2006. From: www.columbia.edu/ mckeever/cv.html. 
- Use of water ${ }^{28}$,

- International Maritime Law ${ }^{29}$,

- International River Law ${ }^{30}$,

- International Law for using Biological Sea Resources ${ }^{31}$,

- Branch whose topic is energy ${ }^{32}$,

- International Law branch for using Biological Resources ${ }^{33}$,

- Air Protection ${ }^{34}$,

Branch that treats protection of flora and fauna around the World ${ }^{35}$, as the others branches, in process of continual establishing and development -- establishing and development expressed through continual developing of rules connected with their group objects, rules applied for regulating some of the ecological-law relation elements, or applied for regulating some other matter not necessary purely ecologically, by which, also and parallel, create law elements ecologically useful, and

28 For example see: Convention on Fishing and Conservation of the Living Resources of the High Sea. At UNEP Ref. Series 3, Barcelona Convention for the Protection of the Mediterannean Sea Against Pollution, February 16, 1976, U.N.T.S. Reg.\# 16908, reprinted in 15 I.L.M. 290, Year 1976.

29 With so many elements exceptionally explained in massive book by: TETLEY, William: International Maritime and Admiralty Law, Q.C. Montreal, (Quebec, Canada): Éditions Yvon Blais, 2003.

30 See, for example: BOURNE, C. B.: International Law and Pollution of International Rivers and Lakes, The University of Toronto Law Journal, Vol. 21, No. 2, Toronto, (Canada), 1971, pp. 193-202.

31 For example, see: DUPUY, René-Jean \& VIGNES, Daniel: A handbook on the new law of the sea. Leiden, (Netherlands): Martinus Nijhoff, , 1991, pp. 993-996.

32 Treated, for example, at the level of law science at the journals like: Oxford Journals Law Journal of World Energy Law \& Business, Oxford, Publisher: Oxford Journals.

33 See: REDGWELL, Catherine \& BOWMAN, Michael (Editors): International Law and the Conservation of Biological Diversity, London (Great Britain): Kluwer Law International, 1996.

34 See, for example: Treaty Banning Nuclear Weapon Tests in the Atmosphere, in Outer Space and under Water. In: JOLDZIC, Vladan \& MILICEVIC, Gordana. The Environment and International Agreements of Importance for the Federal Republic of Yugoslavia, Belgrade (Federal Republic of Yugoslavia): Federal Ministry for Science, Development and the Environment, 1995, p. 72; Convention on Long-range Transboundary Air Pollution [1979]. See: JOLDZIC, Vladan \& MILICEVIC, Gordana: The Environment and International Agreements of Importance for the Federal Republic of Yugoslavia, pp. 61-63; Vienna Convention for the Protection of the Ozone Layer [March 22, 1985]. See: JOLDZIC, Vladan \& MILICEVIC, Gordana: The Environment and International Agreements of Importance for the Federal Republic of Yugoslavia, pp. 64-65; Convention on Environmental Impact Assessment in a Transboundary Context, February 25, 1991, 30 I.L.M. 800, 1991.

35 See legislations, for example, of: Japan: Law for the Conservation of Endangered Species of Wild Fauna and Flora (Law No 75), Tokyo, Publisher: Ministry of the Environment, Government of Japan, 1992. from: http://www.env.go.jp/en/nature/biodiv/law.html) and Australia: Flora and Fauna Guarantee Act 1988 (Victoria), From: Victorian Consolidated Legislation, http://www.austlii.edu.au/au/legis/vic/consol_act/fafga1988205/. 
included them into development of ecological law regulation on the international level.

Entering the international law relations on the occasion of the environment, there should be always on mind, and insist upon the fact, that International Environmental Law develops through practice of conclusions of international contracts, on basis of using general law rules, as well as on formulating new special rules, on condition that they are consisted under massively adopted contracts, which treat some of the ecology law relation questions. In the other words, sources of International Law lie in common will of states, so, that sources itself, in formal sense, are concrete law acts through which law rules are manifested. By the act of ratification, as an act of expressing sovereign state will, these rules become integral part of positive Ecology Law (legislation), of Serbia also, where the key elements of relation between the International, and Internal Ecology Law of sovereign state are reflected ${ }^{36}$.

\section{Relation between Ecology Law and Administrative Law}

Administrative Law, as a part of law science, but also as a part of positive law of sovereign states, represents very complex law branch that deals with specific kind of law relation: Administrative Law relation, in all its complexity ${ }^{37}$. It is based, as a part of positive legislature, before all, on norms which are used for regulation of social relations in connection with the organization and activity of public administration ${ }^{38}$.

Diferentia specifica of Administrative Law relation is expressed by the fact that one of the sides in this relation is by rule, the organ of the state administration ${ }^{39}$. Exceptionally, such side in legal relational could be an organization as well (not the organ of the state administration), authorized, by law, or resolution conceived upon law, for performing concrete Administrative Law duties, which means that this organization possess specific public authorizations.

36 See: JOLDZIC, Vladan: Conventions of Importance for the Protection of the Environmental and Interests of Republic of Serbia; Belgrade, (Serbia): Institute for Criminological and Sociological Researches, 2006, pp. 30. - 44; JOLDZIC, Vladan: The Environment and International Agreements of Importance for the Federal Republic of Yugoslavia, pp. 17-26.

37 Administrative-law relations see closer, for example, at handbook: Council of Europe (Handbook): Administration and You: Principles of Administrative Law Concerning the Relations Between Administrative Authorities and Private Persons, Strasbourg (France): Council of Europe, 1997, p. 16, 17 and 26.

38 POPOVIĆ, S. Administrative Law - General Part, p. 4.

39 POPOVIĆ, S. Administrative Law - General Part, p. 7. 
By doing Administrative Law duties, the organs of the state administration, and the organizations that are authorized for specific jobs, within their authorization (defined by acts and sub-statutory acts), "concerning specific subjects, appears toward another subject of concrete relation with stronger will - with authority, with orders which are obligatory for subjects to whom they are related ${ }^{40}$." This is the second, key diferentia specifica of Administrative Law concerning other law branches ${ }^{41}$. In Administrative Law relation authorized subject appears with stronger will. "By its disposition, he obliges other subject even against its will" ${ }^{42}$," by rule (mostly) with the act in the form of decision, act which conceives the above-mentioned relation. Authorized subject brings decision on the base of laws and sub statutory norms (in the form of addendums). By such legal act: Decision, authorized subject form mentioned relation. Authorized subject form his decision on the basis of norms that are regulating some desirable side of environmentally oriented public relation, and norms that authorize him as a part of administrative establishment, in concrete Administrative Law relation. Therefore, the main characteristic of Administrative Law is that its basic -- general subject is: Administrative Law relation, as well, as all law elements that have influence on its formation and development.

Ecology Law for its basic subject has ecology-law relation, this mean: human relation, regulated by norms, formed on occasion of some of the objects, which is expressed as a constructional element of the ecos. In their narrower determination, those elements are expressed as a group and individually grammaticat ${ }^{43}$ and protected objects inside ecology-law relation ${ }^{44}$. The regulation itself of these relations, in practice, is very often based upon rules of Administrative Law logic conception. Therefore, by expressing superior will of the authorized subject. That is the common line of the Ecology Law with the Administrative Law, from where it absorbs important part of its logic and application. Things that differentiate them are:

a. Type of relation, and

b. General object of regulation.

40 POPOVIĆ, S. Administrative Law - General Part, p. 7, passage 4.

${ }^{41}$ For example: In relation with Civil-law relations, characterized with formal equality of the wills.

42 Popović, S.: Administrative Law - General Part, p. 8.

43 More often, but not ever.

44 It is useful to know that grammatical object is, in Criminal Law theory, object on which any criminal activity was done. It is not necessary that this object is at the same time, object on which will be produced consequences. Also, we can see that criminal activities are pointed on - so called object of offence. May be that the object which we observe is by legislation protected object, object on which we can see results (consequences) of criminal activity? In many cases: a.) grammatical, b.) object of offence, and c.) protected object, is the same object, but not in every case. In accordance with the Criminal Law theory we can, for the purpose of the Ecology Law, say that: Grammatical object is object on which activity of ecology law relation was done, At the place of the object of offence is object of activity, and, of course, Ecology Law also has protected objects. 
As we have already noticed, Ecology Law regulates ecology-law relation, Administrative Law: administrative-law relation.

Object of regulation and law treatment of the Ecology Law is ecology-law relation based on ecological rights and values, observed as entity, as its general object.

General object of Administrative Law is expressed as a public law relation.

Ecology Law, in great part of its development, has to rely upon the Administrative Law elements realizing. Very often to exists through the application of Administrative Law principles and norms. Clearly, some of these principles, as well as mentioned norms, observed by: law-logical, normative-hierarchical, or dogmatic method, have their different places in the Administrative and the Ecology Law system precisely, because of mutual differences between general subjects of the two observed law branches. This is the main reason why their general subjects and those mentioned principles, of the Administrative Law and the Ecology Law, are the elements of their mutual demarcation, also of the necessary cooperation.

\section{Relation between Ecology Law and Civil Law}

Main characteristic of Civil Law is that it regulates property relations between persons (physical or artificial) as subjects of law and legislature. These relations are expressed as a general object of studying and regulation by Civil Law. Regulation itself, of those relations, is based, mainly, on dispositive rules - rules expressed in so called dispositive norms, norms that permit choice (disposition) in personal approach to the concrete law relation forming. This means that subjects, who are independently entering mentioned relation, are forming, by their will, dispositions for regulation of concrete relation, or relations, on the base of the general rules and within the scope of Civil Law. In forming of disposition, or dispositions, they formally possess equal will. This means: Possibility of its expression in making concrete law relation. At the same time, this individuality in regulation means ability for subjects, in accordance with their will, to re-regulate, or brake up this particular relation.

Ecology Law, in arranging the ecology-law relation, does this by norms which possess imperative nature (so called ius cogens norms). It orders bounds to behavior toward goods that make $e \cos ^{45}$. Subjects who are stepping in ecology-law relation have not any opportunity for dispositive behavior, and their will, in principle, can not be expressed by dispositive rules. The only exception would be ecology-law relation conceived between subjects of law, when those subjects decide, by their will, to make

45 Word based on the Old Greek oicos, Latin ecos, in modern languages: environment. 
contribution to eco values, contribution on which they are not obliged by any ius cogens norm of the legislation oriented on the ecology law field. That mean, in essence: They are conceiving ecology-law and civil-law relation, and from this reason is present freedom, as well as equity of their will, in forming of disposition (dispositions) by which the property relation, composed within wider ecology-law relation, is regulated. This means also that such relation treats at the same time, by same legal act, not only relation concerning propriety, but a wider one: ecology law relation.

Other possibility between ecology law and Civil Law relation exists in making ecology-material damage to some subject of law, when the committer has the duty, by the rules of Civil Law, to compensate, or repair, produced damage ${ }^{46}$. This kind of relation is very often in reality.

With regard to noticed contact points and interlacing of Ecology and Civil Law, the question arises: On which way, in reality, we can fix the boundaries between these two kinds of relations? Answer is, in essence, very simple. As we have already stressed, the Civil Law relations are characterized by dispositive, and the Ecology Law relations by norms of imperative nature and subject will inequity (that follows from it). Thereby, it is useful to discern:

- Toward which kind these concrete norms belong to, in observed real law relation, and

- If both sides are present, then, which norms are primary?

\section{Relation between Ecology Law and Penal Law}

Penal Law is complex law branch, which consist of three disciplines:
a. Criminal Law,
b. Economy Violation, and
c. Infringement Law.

Their common characteristic is ordering of sanctions for prohibited behavior of law subjects, defined precisely by law (so called incrimination -- determining the law being of the offense). By definition, the most important element of this trias (L. trias - trio) is Criminal Law -- mostly because of greatness of danger, which characterize criminal acts. Committers of those offenses, in majority of states, can only be law responsible physical ${ }^{47}$, but in a small number of fresh criminal codes,

46 See: SALMA, J.: Civil Law Protection of the Environment, Belgrade, At: Legal Protection of the Environment, Belgrade (S. F. R. of Yugoslavia): Naučna knjiga, 1990, pp. 74-80.

47 For example, in German Criminal Code, of the year 1875, amended at the Year 1994. See original text: Strafgesetzbuch Der Bundesrepublik Deutschland,Verfassungsorganen des Bundes vom 11. August 1999 (BGBl. I S. 1818). 
also can be artificial persons to ${ }^{48}$.

Economy violations and infringements can commit not only physical, but artificial (legal) persons also. These two kinds of incriminated behaviors are mutually different on the base of three elements:

- Economy violations are offenses expressed by economic activities of subjects $^{49}$,

- While infringements can be committed with any other kind of act -economical or uneconomical,

- Also, with the heaviness of expressed jeopardize, or violation of protected good, which is, generally, with the infringements less incomparable.

Contact point of Ecology and Penal Law is found in fact that by the norms of Penal $\mathrm{Law}^{50}$ is given protection to the eco values -- by incrimination of the behavior opposite to the material norms of ecological character ${ }^{51}$. This means that such behavior is incriminated and sanctioned by the positive law. These Ecology Law norms are appearing as a material-law base for forming all three kinds of incriminations:

- Criminal acts, economy violations, and infringements, dedicated for protection of eco values ${ }^{52}$, but, at the same time, comprehensibly, the largest numbers of those rules are, in many states, also for health, body integrity, and man's life protection.

48 See, for example, Article 121-2 of the French Penal Code (Cod Penal du 5 Fevrier 1994, 15 Journal Officiel du 2 février 1994 en vigueur le 1er mars 1994.

49 Activities that, also, can be of environmental importance. See, for example: South Australia's Environment Protection Act of 1993 (From: www.legislation.sa.gov.au), text which incriminate, with: Section 79[1] criminal liability for "serious environmental harm," and Section 80[1], which incriminate criminal liability for "material environmental harm," activities of man, as well as of artificial persons, also.

50 As a branch of some observed positive legislation.

51 On this theme se closer: JOLDZIC, Vladan: Environmental Crimes in Law and Reality (Published at Serbian language: Ekološki kriminalitet u pravu i stvarnosti), Belgrade, (Federal Republic of Yugoslavia): Institute for Criminological and Sociological Researches, 1995, pp. 20-24.

52 Fact which is clearly visible from: Australian Environment Protection and Biodiversity Conservation Act 1999, legislative text that give legal basement for incriminations in positive Criminal Code Act 1995, Act No. 12 of 1995, as amended [amendments up to Act No. 137 of the year 2000]. 


\section{Conclusions}

In our, with this text expressed, scientific efforts at the field of Environmental law development and applying we have pointed at mutual relations of the Ecology law and the other law branches, relations at the same time of key interest for Environmental law branch and the other connected law and legal branches. We had done efforts to point at: at first place, law-logical differences between observed law and legal branches, and, at the second place, their connections and mutual importance. Of course we had not treated all, but branches of utmost interest for our field of researches. Such work produced some results - our conclusions. What we, among in text already remarked, can conclude summarily?

1. Primary, it is evident that ecology law efforts, efforts for developing at the level of international community and law, as well at the level of states, obviously are not possible out of constitutional boundaries.

2. If we preview environmental problems through time, it is obvious that relation between Ecology Law and the International Public Law is in process of feedback enhancing.

3. Whatever simple research effort we can do, in any state, as well as at the level of international community, relations between the Ecology Law branch and the Administrative Law branch are unavoidable and of utmost interest.

4. Having in mind that Environmental Law forms protective law and legal elements for environmental values and rights it is obvious that relations between Ecology Law and Civil Law have special importance. Civil Law threats worth. This means anything that can be measured through money. Any environmental value also has worth that can be measured at the same way. From this reason also any environmental damage can be measured, inside state borders, but also outside and at the international territories.

5. - If we accept previous four conclusions it is clear that all treated and explained need some kind of efficient guaranty. Such guaranty is adequate criminal law and legislature, as we explained under Part 6 of our text.

Of course, our researching do not produce complete picture of all the possible interconnections, differences and boundaries between ecology and the other law branches, but the author has state that presented are of utmost importance. 


\section{Bibliography}

ANZILOTTI, Dionisio: Cours de Droit International, Vol. 1, Paris (France): Librairie du Recueil Sirey, 1929. AUSTRALIA: Flora and Fauna Guarantee Act 1988 (Victoria), From: Victorian Consolidated Legislation. http://austlii.edu.au/legis/vic/cpnsol_act/fafga1988205/.

. Australian Environment Protection and Biodiversity Conservation Act 1999.

. Criminal Code Act 1995, Act No. 12 of 1995, as amended [amendments up to Act No. 137 of the year 2000], from: http://www.austlii.edu.au/au/legis/cth/consol_act/cca1995115/.

AVRAMOV, Sima. \& KRECA, Milenko: International Public Law (Medunarodno javno pravo), Belgrade, (Socialistic Federal Republic of Yugoslavia): Savremena dministracija, 1993

Barcelona Convention for the Protection of the Mediterannean Sea Against Pollution, February 16, 1976, U.N.T.S. Reg.\# 16908, reprinted in 15 I.L.M. 290, 1976.

BELGIUM . The Constitution Of Belgium, Coordinated text of 14 February 1994, a translation made by the Belgian Senate, version 21.1.1997.

BOURNE, C. B.: International Law and Pollution of International Rivers and Lakes, The University of Toronto Law Journal, Vol. 21, No. 2, Toronto, (Canada), 1971.

BRAZIL Constitution, Adopted on: 5 Oct 1988, from: http://geogetown.edu/pba/Constitutions/Brazil/ brtitle9.html.

BUSINESS \& HUMAN RIGHTS RESOURCE CENTRE. On the Horizon - A practical bulletin on what is ahead in the field of business \& human rights, Issue 8, London (United Kingdom): Business \& Human Rights Resource Centre, Monday 8 Dec 2008, p 1-7, at: http://www.crsdd.uqam.ca/Pages/docs/pdfMedias/ On $\% 20$ the $\% 20$ Horizon $\% 20-\%$ Issue $\% 208 \% 20-\% 20$ Dec $\% 202008 \% 5$ B1\%5D.pdf, From: www.businesshumanrights.org.

Convention on Environmental Impact Assessment in a Trans-boundary Context, February 25, 1991, 30 I.L.M. 800, Year 1991

Convention on Fishing and Conservation of the Living Resources of the High Sea, At UNEP Ref. Series 3, Geneva (Switzerland), Year 1983.

DELLA CANANEA, Giacinto: Administrative Procedures and Rights in Italy: A Comparative Approach, Italian Journal of Public Law, Volume 2n 1, Milano (Italy): Bocconi University, 2010, p. 207-215.

DISCUSIONS [Rasprave] Vol. XII, Ljubljana (Slovenia): SAZU, Year 1981.

DUPUY, Rene-Jean (Editor): The Future of the International Law of the Environment, Hague (Netherland): Kluwer Law International, 1985

DUPUY, René-Jean \& VIGNES, Daniel: A handbook on the new law of the sea. Leiden, (Netherlands): Martinus Nijhoff, 1991.

Encyclopedia of the Law (Enciklopedija prava), Belgrade (S.F.R. Yugoslavia), Publisher: Savremena administracija, Year 1989.

FRANCE. Code pénal, Version consolidée au 7 janvier 2011, from: http://www.legifrance.gouv.fr/

Constitution fédérale du 18 avril 1999, état le 18 septembre 2001, at: www.admin.ch/ch/f/rs/101/ index.html.

GERMANY . German Criminal Code, of the year 1875, amended at the Year 1994. See original text: Strafgesetzbuch Der Bundesrepublik Deutschland, Verfassungsorganen des Bundes vom 11. August 1999 (BGBl. I S. 1818).

Fundamental Law of the Federal Republic of Germany, version dated at the March 18, 1971.

. Grundgesetz für die Bundesrepublik Deutschland (GG), vom 23. Mai 1949 (BGBl. S. 1), zuletzt geändert durch Bundesgesetz vom 27.10.1994. (BGBl. S. 3146), (Constitution of Federal Republic of Germany), GREECE . Constitution of Greece, Adopted: 11 June 1975 [Status: 1986], revised at April $6^{\text {Th }}$ 2001, Official translation of the Parliament, Athena: Eptalofos, 2004.

ITALY . Costituzione della Repubblica italiana (Constitution of the Italian Republic), Gazzetta Ufficiale, No. 298 on 27 December 1947), Document gathered from: http://www.servat.unibe.ch/icl/it00000_html.

JAPAN: Law for the Conservation of Endangered Species of Wild Fauna and Flora (Law No 75), Tokyo, (Japan): Ministry of the Environment, Government of Japan, Year 1992. from: http://www.env.go.jp/en/ nature/biodiv/law.html 
JOLDZIC, Vladan: Developing of the constitutional fundaments - prerequisite and basement for good practice at the field of environmental crimes protection, chapter of book: Prevention of Crimes and Social Deviation: European and Regional Good Practice. Belgrade, (Serbia): Institute for Criminological and Sociological Researches monograph, 2011.

JOLDZIC, Vladan: Environmental Law - General and Separate Part, Belgrade (Serbia): Institute for Criminological and Sociological Researches, 2009.

JOLDZIC, Vladan: Ecology Law - General part - Or on the Elements Necessary for the establishing and existing of the Independent Law Discipline (Personal Observations). Revista Mestrado em Direito. Direitos Humanos Fundamentais, Vol. 9-1, Osasco: UNIFIEO - Centro Universitario FIEO, 2009, p. 127-169.

JOLDZIC, Vladan: Conventions of Importance for the Protection of the Environmental and Interests of Republic of Serbia; Belgrade, (Serbia): Institute for Criminological and Sociological Researches, 2006.

JOLDZIC, Vladan: Constitutional - Legal Fundaments of the Environmental Protection in the Federal Republic of Yugoslavia; Belgrade (Serbia): Environment: Federal Ministry for Development, Science and Environment, No 1, 1995.

JOLDZIC, Vladan: Environmental Crimes in Law and Reality (Published at Serbian language: Ekološki kriminalitet u pravu i stvarnosti). Belgrade (F.R. Yugoslavia): Institute for Criminological and Sociological Researches, 1995.

JOLDZIC, V. \& MILICEVIC, G.: Constitutional - Legal Fundaments of the Environmental Protection in the Federal Republic of Yugoslavia, Edition: Environment, No. 1, Belgrade (Federal Republic of Yugoslavia): Federal Ministry for Development, Science and the Environment, 1995.

McKEEVER, Kent: Researching Public International Law, Columbia University Law School, Library: Pegasus Arthur W. Diamond Law Library Research Guides, Last Updated January 2006. From: http://www. columbia.edu/mckeever/cv.html.

OXFORD JOURNALS. Law Journal of World Energy Law \& Business (Oxford Journals).

POPOVIC, Slavoljub: Administrative Law - General Part, Belgrade (Yugoslavia): Savremena administracija, 1989, p. 15.

POPOVIC, Slavoljub: About Environmental Protection Law, or Ecology Law [O pravu zaštite životne sredine, ili ekološkom pravu]. In: Collection of the Law Faculty, Novi Sad, Serbia, (S.F.R. Yugoslavia): Savremena admnistracija, 1980.

POPOVIC, Slavoljub: Water and Air Protection of the Soiling [Zaštita vazduha i voda od zagađivanja], In: Collection of the Law Faculty, Novi Sad, Serbia, (S.F.R. Yugoslavia): Savremena admnistracija, 1980.

POPOVIC, Slavoljub: Water and Air Protection of the Soiling (Zaštita vazduha i voda od zagađivanja), Collection of the Law Faculty, Novi Sad (Serbia): Law Faculty of Novi Sad, 1980

REDGWELL, Catherine \& BOWMAN, Michael (Editors): International Law and the Conservation of Biological Diversity, London (Great Britain): Kluwer Law International, 1996.

RENDTORFF, Jacob Dahl: Responsibility, Ethics and Legitimacy of Corporations, Copenhagen (Denmark), Editor (Publisher): Copenhagen Business School Press, Year 2009, p. 416.

SALMA, J: Civil Law Protection of the Environment, Belgrade, At: Legal Protection of the Environment, Belgrade (S. F. R. of Yugoslavia): Naučna knjiga, 1990

SHUANG-HONG, A. O.: Review and Prospects: a Research on the Administrative Law Relations, Journal of Fujian Public Safety College, No 2, Changsha, (China): Fujian Public Safety College, p. 80-86, 2007.

SERBIA . Constitution of the Republic of Serbia, Official Journal of the Republic of Serbia, No 83, 2006. SWITZERLAND . Federal Constitution of the Swiss Confederation, of April 18, 1999, version of September 18, 2001, from: http://www.admin.ch/org/polit/00083/index.html?lang=en.

TAUTENBERG, Jonson: The International Law - Some Basic Viewpoints, in: DUPUY, Rene-Jean (Editor): The Future of the International Law of the Environment, Hague (Netherland): Kluwer Law International, 1985. TETLEY, William: International Maritime and Admiralty Law, Q.C. Montreal, (Quebec, Canada): Éditions Yvon Blais, 2003

Treaty Banning Nuclear Weapon Tests in the Atmosphere, in Outer Space and Under Water [Year 1963], at: UNEP Register of International Treaties and Other Agreements in the Field of the Environment", Geneva (Switzerland), Year 1996.

UNITED NATIONS, TREATY SERIES. Vienna Convention on the Contractual Law, at: United Nations Treaty Series, vol. 1155, p. 331. 